\title{
The Great Regions: Wide Europe and China Make the Future Global Growth
}

\author{
Joyce Juan Ni
}

Published online: 29 April 2009

(C) Springer-Verlag 2009

\begin{abstract}
EU is an economic super power and ASEAN is an economic mini power. In demographic view, EU is a mini power and ASEAN is a super power. EU has a kind of hydraulic power that no other institution has. Could it be that Europe as a whole is insulated against the sufferings and the fate of irreversible relative decline in the world? Perhaps like China, Europe need not be down and out forever. If one strategy is not working, more of the same is probably not the solution. So, Europe needs to do things differently-all depend on transparent governance and wiser policies.
\end{abstract}

Keywords Wide Europe $\cdot$ China · Growth

JEL Classification $\mathrm{O} 40 \cdot \mathrm{N} 10$

\section{Wide Europe}

Europe's Economic Model

The European economic model is a market economy with a strong role for the government, which establishes rules for goods, services, labor, and capital markets; manages macroeconomic policy; and pursues a proactive social policy (Fort and Webber 2006).

Over the past few years, the growth of Euroland has really been stagnating. Since the beginning of European Monetary Union (EMU) in 1999, growth has averaged only $1.8 \%$, compared with $2.8 \%$ in the United States and $2.5 \%$ in the United Kingdom (source: OECD, National Statistics Authorities). In 1990-2002, GDP

\section{J. J. Ni ( ()}

The University of Hong Kong, Hong Kong, China e-mail: joyce.ni@business.hku.hk 
growth per capita was higher in Euroland than in the United States (source: OECD, National Statistics Authorities). In more recent years, however, even per capita GDP growth in Euroland fell short of rates reached elsewhere. In the products being produced, 10 years ago, Europe and United States both produced about the third of the products being produced into the market around the world. Today, Europe's share is down to $20 \%$ of falling and U.S. share is over $60 \%$.

There are several reasons for the sluggish economic growth. First, the market is saturating and there is fierce competition in the market. European's weakness, difficulties to adjust to more intense labor competition, has been an important reason for Euroland's lackluster performance in recent years. All European states had strategies to create employment. However, they did not work. The reason for that is that there are too may priorities in the system. It is the problem of delivery and decision making. Thus, the whole system is too complicated and too slow. Therefore, there is no sense of ownership, no sense of possession and no sense of responsibility. Secondly, the emergence of China and Southeast Asian countries as major suppliers of manufactured goods and the accession of Central European countries to the EU have increased low cost competition for European producers. With Europe wages sticky, non-wage labor costs high, and labor mobility very limited, low-wage competition from abroad has put upward pressure on unemployment (Keene 2005).

Thirdly, the lesson we could draw from the past decade is that combine social justice with economic success. Job is the best social inclusion. Once we got someone into the job, then next is to get the one a better job, so raising skills and raising skills is also a crucial part of competitiveness. What we have to do is pursue other social and environmental goals but in ways that enhance competitiveness in stead of undermining or threatening to destroy it. That is where too often individual member states but also European Union as a whole has gone wrong in the past.

Euro area annual capital stock growth allowed from about 3\% during 1981-1990 to only $2 \%$ in 2003. Partly offsetting this, total hours worked stagnated in recent years after having fallen significantly during the 1970s. However, total factor productivity growth-which reflects the economy's ability to leverage growth of capital and labor input through technology - fell by about one half since the mid1990s. By contrast, total factor productivity growth in the United States almost doubled during this period (Blanchard 2004). Without a sizeable increase in productivity growth, it is hard to see how Europe trend growth can pick up to its past levels and narrow its gap with the United States. In a recent study, Deutsche Bank estimated Euroland potential growth at $1.75 \%$ in the annual average of 2003-2010 (Deutsche Bank 2003). This estimate was based on a contribution from total factor productivity growth of $0.6 \%$ points, from capital input growth of $0.7 \%$ points, and from labor input growth of $0.5 \%$ points. For this to materialize it was assumed that productivity and capital input growth stabilized slightly above recent levels, while labor input growth accelerated on the back of working-time extension, higher participation rates, and lower structural unemployment.

Last but not least, we know pretty well that something needs to be done in order to improve performance and competitiveness. It means to accept the market rules. It 
implies to accept the environment where enterprises can perform in their best way. It means to accept competition as the most important element for the economy.

\section{The Challenges}

The integration of lesser developed and formerly communist countries into a world market of goods and services, the fall of the barriers to international capital flows, and rapid technological progress led largely by the United States have put additional strain on the European economic model (Redwood 2005). Moreover, local governments may have different objectives. The objective, of Europe as a whole, is competitiveness, jobs and growth. Many of the local companies are putting controls of costs to hit of investments and jobs. The challenge of the struggle is how to implement the governance agenda when member states have different objectives.

In all European counties, the agricultural sector has been under intense government management through the Common Agricultural Policy of the EU.

Over time, direct government meddling in industry has receded. Britain has done better than the average of the European over the last decade. What they have done was that they combined a platform of micro economy stabilities with a whole series of structural reforms. The welfare security system brought unemployment to a low level and created an environment to bring into the employment, and at the same time, partly driving that, they see hundreds of thousands of establishments established. The importance of structural reform is clear from their experience. And they are not the only one get it right. Following the British example, continental European governments - especially Italy and France-have privatized a large part of their extensive industrial holdings. At the same time, however, governments have continued to redistribute income and fortify the welfare state. Hence, government spending in general and spending on social benefits in particular have remained much higher relative to GDP in Europe than elsewhere, notably in the United States. For instance, during 1995-1998, 29.1\% of its GDP was used for social spending in France, while $27.4 \%$ in Germany and $24.5 \%$ in Italy, respectively. On the other part, United States spent $15.1 \%$ of its GDP on social spending and Canada $18.4 \%$ (OECD 2001).

\section{Riding into the Sunset?}

In his impressive economic history of the world, The Wealth and Poverty of Nations, David Landes traces the rise and fall of several European powers since the middle of the last millennium (Telo 2007). The question is how can we bring the European economy back to the track?

The innovation and driving technology are very important in EU, people rarely talk a lot about it, but they are the key things that keep people with current living standard. Europe will never eligibly compete with the international low-pay labor. Europe has its tradition in front-edge technology, such as German has the top automobiles and Italy has elegant fashion in the world. Also, as structure reforms in the labor market, government really did a lot, but they are far from enough. Lastly, a more competitive governance system which is easier and more transparent is highly 
needed. If a country reforms one year by the other, it is very difficult for people to decide where the investments to go.

\section{Asia}

Ascendant Asia

There is a saying Napoleon says about two hundreds years ago. He came home and pointed to a map where China is on the wall and said "That is a sleeping dragon. Let him sleep. If he wakes, he will shake the world." That dragon is widely awake and whether feared or excited, it is the time for the world start shaking. For the past decades, Asia has been a major driving force of world's economic growth. Regional power houses such as Japan, China and India are enjoying a long-run trend of reducing volatility of outputs, financial markets and interest rates. There is now a rebalancing going on in growth across countries. So the world is no longer independent as a local motive United States. In fact, the emerging markets comprise more than half of the world economy, which can be a pedal. There is also rebalance in the countries. If we look at China, we see real policies are encouraging consumptions and composing aggregate demand, and real policies are encouraging reduction of exports, which is healthy thing for China.

This part of the world, Asia, has enjoying the spectacular growth for decades. With the promising signs, with the control but non-insignificant change in the Chinese exchange rate, all of those things suggest that China will continue to growth. Of course, there may be unpredictable shocks over the years. We need to be weary of it in the forest, which we economists can not see it.

Most Asian economies should be able to withstand moderately higher U.S. interest rates - as they did in the late 1980 s - or a gradual decline in the dollar, as long as they themselves can maintain accommodative financial conditions and sustain steady increases in domestic demand. However, a very sharp decline in U.S. growth, or in the dollar, would have serious implications for the region because of Asia's continued heavy dependence on exports to North America (Welfens 2006).

One of the key of the development rests in the capital markets. The facts are clear that the capital markets are in deep, people are skilled over time and governments all over the region have moved the power from the political arena to the market place. It means, in a fundamental sense, Asia as a whole is benefit from better policies, not to say China, 1.3 billion people with economic growing in double digit for more than a decade.

After years of significant dependence on export-led growth, one of the broadest changes taking place in Asia is the prospect of a stronger role for domestic and regional demand in driving growth. Most Asian economies continue to be significant exporters of a wide range of goods and services to the United States and the EU-and final demand in those economies remains critical to the economic health of the Asian region. A recent International Monetary Fund report pointed out that of all exports from emerging Asia, $81 \%$ go directly or indirectly (in the form of 
exports to other Asian nations for assembly into final products shipped outside the region) to non-Asian industrialized countries (IMF).

China did great job. The average GDP growth rate over the last decade was over $10 \%$. CPI was low, even was PPI as people concern about the capacity. And the most important thing is, if we look at corporate sectors, the whole industries grew about $34 \%$. Therefore, low price and international debts and strong growth with increasing profit earning capacity strongly imply China improves efficiency.

China is likely to continue to experience annual trade deficits with most of the rest of Asia, but rising surpluses with the United States or the EU. Robust domestic demand in the future will depend in part on continued redeployment of China's high domestic savings and from inefficient state enterprises and into more productive investments, broader-based growth in rural China, and a currency adjustment.

India, the other power engine in this region, has joining the fast-growth club. The key is how sustainable is it? How can India keep rising and keep the moment going? The good news is that there is an up surge in investment. There is still also a huge need for investment. Some investments are in rural areas. It means India primarily constrained at the moment by the problem on the agriculture side where we do need to put in a whole set of policies in. The other is investment in general infrastructure. India is lagged behind some countries in Asia in terms of infrastructure necessary for growth. As it demonstrated its ability to grow, it has to be supported by a very large investment. Gratefully, the financial markets, the policy framework, the investment climate, the involvement of private sector in infrastructure investment, all of these point to a positive direction. India is a huge state and fortunately, the consensus is very probably that it will continue growing.

For China to become a real super power, it is paramount to culture its influence. Foremost, China's great accomplishments have to be achieved with southeast countries. Economic integration with southeast countries and Japan has been already strong. There is also a new spirit of intra-regional cooperation, and a strong push to put in place more formal institutions to facilitate that cooperation. The 2001 Chiang Mai Initiative produced agreement on commitments of $\$ 35$ billion for bilateral currency swap arrangements, although improving payments balances have virtually eliminated the need to draw on these now. As intra-regional trade continues to grow, there is increasing focus on broader currency cooperation-and ways to avoid excessive exposure to the dollar. One goal is to make a larger share of investment in local assets. The Asian Bond Fund Initiative (ABF2) — announced by the central banks of East Asia, Australia, and New Zealand-would create an Asian Fund of Funds, which would invest in bond funds in individual East Asian countries. Besides, China relies on Shanghai Cooperation Organization that has really been strengthened in last couple of years.

As the aftereffects of the 1997 crisis wear off and technology spending in the G7 nations strengthens, investment in the emerging economies of the region, particularly in industries geared to high technology exports, is gaining momentum. That, in turn, is boosting employment and private consumption. The improved condition of banks in the region, due to reform and restructuring, together with their greater emphasis on consumer-oriented financial products, such as mortgages and credit cards (which banks advanced in recent years to reduce dependence on 
sluggish export financing business during the global downturn), also has boosted prospects for stronger Asian domestic consumption.

Domestic demand is strengthening elsewhere in Asia. In many countries, it is being led by a resurgence of investment spending. Capital spending has been sluggish in much of Asia for some time, largely because the region has been recovering from, first, a period of dramatic overinvestment in the mid-1990s, then from the 1997 financial crisis, and then from the effects of the severe acute respiratory syndrome (SARS). It also bore the effects of the post-bubble weakness in demand for high-technology products in industrialized nation.

Growth in Spurts but Still Challenges in the Region

One of the challenges in ASEAN is that even the agreement of ASEAN level is reached, individual countries will feel political pressure and economic result of agreeing tariff reduction that is implemented in other major countries that domestically protect themselves. The reason is that individual governments and individual countries have political concerns that contain successful individual industries. Therefore, it is always a calculation, even major nations are always looking forward to advantages. And it particularly not clear for the poor ASEAN countries whether it is going to be a great advantage typically if there are going to be winners and losers. There is broad discussion between China, Japan, India and ASEAN on free trade agreements. It also gets a lot of discussions in ASEAN itself. In ASEAN itself, it is likely to see, particularly when the liberation of service, much like what has been in Europe, say liberation of financial service, which for example, is a very important part for trade partners, like Japan. It is likely to get the liberation among Thailand, Malaysia, and Singapore, but not probably between other countries. A major issue also here is high inflation on the ASEAN economies. Emerging economies have generally less opportunities to deal with this, because the heavy dependence, particularly agriculture sector, like most of the economies, including European economy, is heavily subsidized.

Now countries are realizing the fruits of their efforts-especially the completion of "supply-side" adjustment in the form of stronger corporate balance sheets and the improved lending capacities of the now stronger banks. They are starting to see a pickup in corporate capital spending, which in turn is driving increases in disposable income and greater consumption.

\section{Connection of Europe and Asia}

EU is an economic super power, and ASEAN is an economic mini power. In demographic view, EU is a mini power, and ASEAN is a super power. EU has a kind of hydraulic power that no other institution has. People want to be one of it, people want to be in it. The G7 or G8 are the clubs with the assumption that they are the global leaders. But they are the clubs yesterday. Could it be that Europe as a whole insulate from suffers the fate of irreversible relative decline in the world? 
Perhaps, like China, Europe need not be down and out forever. If one strategy is not working, more of the same is probably not the solution. So, Europe needs to do things differently - it is important to combine low inflation, low interest rate, low budget deficit of micro economy environment with very high levels of employment and entrepreneurship. Policies will also have to adjust to address the continued poverty and income disparities in much of the region-they all depend on the transparent governance and wise-looking policies.

\section{References}

Blanchard O (2004) The Economic Future of Europe. NBER Working paper 10310

"Euroland: assessing potential growth", Deutsche Bank Global Markets Research Special Publications, October 1, 2003

Fort B, Webber D (2006) Regional integration in East Asia and Europe: convergence or divergence? Routledge, New York

Keene TR (2005) Flying on one engine. Bloomberg Press, New York

OECD (2001) Economic outlook, No. 69. OECD, Paris, pp 160-162

Redwood J (2005) Superpower struggles: mighty America, faltering Europe, rising Asia. Palgrave Macmillan, Hampshire

Telo M (2007) European Union and new regionalism: regional actors and global governance in a posthegemonic era. Ashgate, Surrey

Welfens PJJ (2006) Integration in Asia and Europe: historical dynamics, political issues, and economic perspectives. Springer, Berlin 